УДК 681.620

\title{
ПОБУДОВА РОЗРАХУНКОВОЇ СХЕМИ ДЛЯ ВИЗНАЧЕННЯ ВЕРТИКАЛЬНОГО ЗУСИЛЛЯ ВІБРОРІЗАННЯ
}

\author{
(c) О. В. Науменко, здобувач, НТУУ «КПІ», Київ, Україна
}

На основе механики процесса виброрезания стопы бумаги, предложена расчетная схема определения силы резания.

\section{Rated scheme of estimation of cutting force was proposed based on the machanics of vibrartion-cutting process.}

\section{Постановка проблеми}

у поліграфічному виробництві різання стосів паперу $\epsilon$ невід'ємною частиною технологічного процесу виробництва книжок і іншої друкованої продукції. Вже більш півтора сторіччя для різки стосів паперу використовують гільйотинний спосіб різання, який в значній мірі визначає технічний рівень одноножових паперорізальних машин. Основним недоліком цього способу є великі сили різання, які виникають при розрізі стосу, величина і характер зміни яких визначається видом руху ножа.

В сучасних паперорізальних машинах найбільш доцільним вважається шабельний рух ножа. Однак, внаслідок великих сил різання і залежних від них сил притискування паперорізальні машини 3 шабельним рухом ножа мають значну енергоємність. Високі вимоги до точності і чистоти обрізу приводять до створення громіздких та металоємних станин машин. Інтенсивний знос ріжучого інструменту викликає великі витрати дорогих i дефіцитних марок сталі, а часті зміни ножів і марзанів знижують продуктивність роботи паперорізальних машин.

Проведені дослідження [1-3] показали, що можливості зменшення вказаних недоліків при існуючому способі різання практично вичерпані. Це приводить до необхідності пошуку і розробки нетрадиційних способів для створення нової технології різання паперу.

\section{Аналіз попередніх досліджень}

Початок дослідження процесу віброрізання стосів листового паперового матеріалу у СРСР поклали праці Д. Ф. Акатьєва [2, 3]. В результаті проведених досліджень вібраційного різання стосів паперу ножем, що вертикально рухається і горизонтально коливається в площині різання встановлено значне зниження зусиль різання, підвищення якості обрізу і точності різу. При цьому передбачалась можливість різання стосів паперу більшої висоти і зменшення необхідної сили натиску. Проведені дослідження показали принципову можливість вібраційного різання стосів паперу, 
проте через складність проблеми ці дослідження не були доведені до практичної реалізації.

У роботі Г. Г. Петріашвілі [1] проведені подальші дослідження процесу вібраційного різання стосів паперу, вироблені рекомендації по практичному застосуванню даного способу у паперорізальних машинах. Автором проведений широкий комплекс теоретичних і експериментальних досліджень, що дозволили визначити раціональний напрямок коливань і вид руху ножа, виявити сутність явищ, що призводять до зниження сили різання, визначити оптимальні параметри процесу віброрізання. Крім того, у роботі запропоновано ряд технічних рішень, що дозволяють значно знизити сили різання при збереженні виробничої потужності машини, а також значно збільшити період роботи ріжучого інструменту.

Дані проведених аналітичних та експериментальних досліджень процесу різання стосів паперу та обрізування книжкових блоків інструментом, що здійснює віброколивання викладено в роботах $[4,5]$. Пошук оптимальних режимів (з огляду на швидкісні, силові та якісні показники процесу різання) здійснювали у низькому й ультразвуковому діапазонах частот коливань леза різального інструменту. Дослідження процесу віброрізання показало значне зменшення сили різання. Так, коли частота становила 160-180 Гц, а амплітуда коли- вань різального інструмента 0,05-0,1 мм, то сила різання становила 156-180 H/см, а за умови частоти 40 Гц і амплітуди коливань 0,8-1 мм сила різання зменшилася до 70-120 Н/см.

Проведений аналіз досліджень свідчить про перспективність застосування процесу віброрізання в поліграфії та створенні на його основі обладнання, яке використовуватиметься у брошурно-палітурному виробництві.

\section{Мета дослідження}

Виходячи з актуальності методу віброрізання і перспективи його застосування в поліграфії, існують запатентовані розробки такого обладнання.

В основу покладена задача створення пристрою для різки листового паперового матеріалу методом віброрізання, за рахунок чого зменшується зусилля різання, а різання відбувається у момент найбільшої лінійної швидкості віброножа.

\section{Результати проведених досліджень}

Проведені дослідження кінематики процесу віброрізання з різними видами руху ножа і напрямками коливання. Встановлено, що вібрації ріжучого інструменту призводять до періодичної зміни швидкості різання на протязі одного циклу коливання, при цьому суттєво змінюються дійсні кути різання. В результаті досліджень різних варіантів віброрізання зазначено, що найменші дійсні кути 
різання $\alpha$ досягаються при нахильно-паралельному русі ножа 3 поперечними вібраціями (рис. а). Де Vy i Vx - відповідно вертикальна і горизонтальна складові швидкості подачі; VB амплітудне значення вібраційної швидкості.

Основними розрахунковими технологічними параметрами при розробці паперорізальної машини є зусилля різання. Найбільших значень при різанні стопи паперу досягає вертикальна складова сили різання, зниження якої при наклонному русі ножа обумовлює трансформація кута заточки. При вібраційному різанні виникає суттєве зменшення дійсних кутів різання $\propto р$. Встановлено, що однією з причин зниження зусиль віброрізання наряду зі зменшенням $\alpha p \in$ упругі деформації стопи паперу. Внаслідок того, що ніж здійснює возвратно-поступальний рух приводячи до періодичної зміни кутів $\alpha р$ сила різання коливається від мінімальної величини до макси- мальної. При цьому, на початку процесу, під дією сили Fр стопа під ножем деформується викликаючи упругу реакцію Fупр; але різання ще не відбувається. Різання починається тоді, коли сила упругості стопи Fупр стає рівною необхідній силі різання Fp. Як тільки швидкість упругої деформації стопи стає рівною вертикальній швидкості подачі різання припиняється і починається стискування. Таким чином процес віброрізання стопи паперу описується як переодичне чередування етапів: стис-різ.

На рис. б представлена розрахункова схема процесу. Де Уупр - упруга деформація стиснення; Уср - висота зрізу; Fo - сила притискування.

Для характеристики зусиль, які виникають у процесі різання, важливе значення має погонне зусилля різання, тобто величина сили різання, яка припадає на одиницю довжини ножа.

$$
\rho=P_{p} / L \quad(H / c m),
$$

де $L$ - ширина стопи, см.

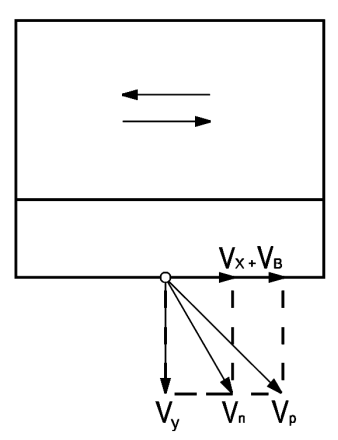

a

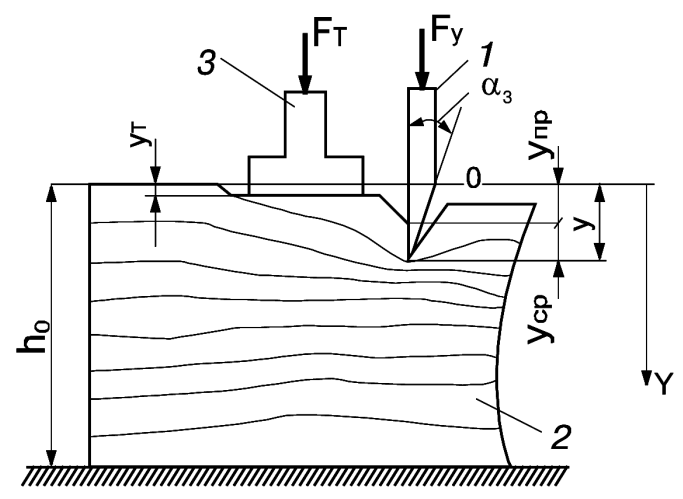

6

Розрахункова схема для визначення вертикального зусилля віброрізання 


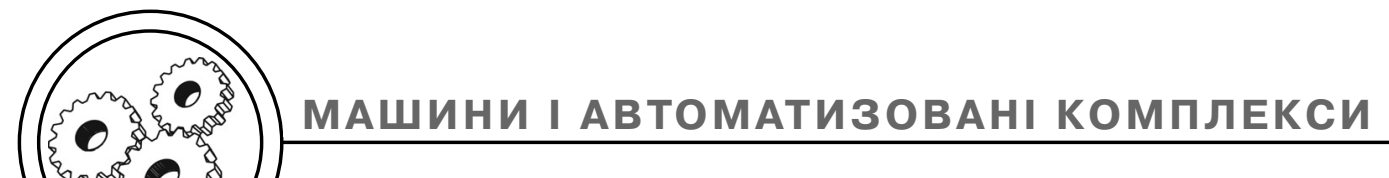

\section{Висновки}

1. Проведені дослідження кінематики процесу віброрізання з різними видами руху ножа і напрямками коливання.
2. Надано розрахункову схему для визначення вертикального зусилля віброрізання.

1. Петриашвили Г. Г. Совершенствование одноножевых бумагорезальных машин на основе комплексных исследований процесса виброрезания, Дис. канд. техн. наук, Львов, 1990. - С. 221. 2. Акатьев Д. Ф. Исследование процесса резания стоп бумаги колеблющимся ножом, Дис. канд. техн. наук, Москва, 1968. - С. 199. 3. Акатьев Д. Ф. О параметрах резания стоп бумаги колеблющимся ножом / Д. Ф. Акатьев // Труды ВНИИполиграфмаш. Высокопроизводительное брошюровочно-переплетное оборудование. Сб. научн. трудов. - Москва, 1983. - С. 68-74. 4. Петриашвили Г. Г. Изучение возможности виброрезания стоп бумаги с низкой и ультразвуковой частотой / Г. Г. Петриашвили. - Львов, 1984. - С. 15. 5. Полюдов А. Н. Виброрезание и исследование возможности применения его резания бумаги / А. Н. Полюдов, Г. Г. Петриашвили, А. Д. Черненко. - Львов, 1981. - С. 9.

1. Petriashvili H. H. Sovershenstvovanije odnonozhevih bumahorezal'nih mashin na osnove kompleksnih issledovanij protsessa vibrorezanija, Dis. kand. tehn. nauk, L'vov, 1990. - S. 221. 2. Akat'ev D. F. Issledovanie protsessa rezanija stop bumahi kolebljushchimsja nozhom, Dis. kand. tehn. nauk, Moskva, 1968. - S. 199. 3. Akat'ev D. F. O parametrah rezanija stop bumahi kolebljushchimsja nozhom / D. F. Akat'ev // Trudi VNIlpoligrafmash. Visokoproizvoditel'noe broshjurovochno-perepletnoe oborudovanie. Sb. nauchn. trudov. - Moskva, 1983. - S. 68-74. 4. Petriashvili H. H. Izuchenie vozmozhnosti vibrorezanija stop bumahi s nizkoj i ul'trazvukovoj chastotoj / H. H. Petriashvili. - L'vov, 1984. - S. 15. 5. Poljudov A. N. Vibrorezanie i issledovanie vozmozhnosti primenenija eho rezanija bumahi / A. N. Poljudov, H. H. Petriashvili, A. D. Chernenko. - L'vov, 1981. - S. 9.

$$
\begin{array}{r}
\text { Рецензент - П. О. Киричок, д.т.н., } \\
\text { професор, НТУУ «КПІ» }
\end{array}
$$

Надійшла до редакції 28.05.12 